\title{
Influence of low- and high-protein diets on insulin and insulin- like growth factor-1 binding to skeletal muscle and liver in the growing rat
}

\author{
BY D. DARDEVET, M. MANIN, M. BALAGE, C. SORNET AND J. GRIZARD* \\ INRA Theix, Laboratoire d'Etude du Métabolisme Azoté, 63122 Ceyrat, France
}

(Received 4 December 1989 - Accepted 12 June 1990)

\begin{abstract}
The influence of protein content of the diet on the plasma concentrations and binding to skeletal muscle and liver of insulin and insulin-like growth factor-1 (IGF-1), was studied in growing rats. Animals with a starting body-weight of $80 \mathrm{~g}$ received for an $11 \mathrm{~d}$ period isoenergetic diets containing $(\mathrm{g} / \mathrm{kg}$ dry matter) 155 protein as controls (MP), or 55 (LP) or 300 (HP) protein. Food was offered as six equal meals/d. Daily food intakes provided adequate amounts of energy. Total plasma IGF-1 increased linearly as a function of dietary protein intake. Plasma insulin was lower in the LP than in the MP and HP groups. Hormone binding was studied in wheat-germ agglutinin (WGA) partially purified skeletal muscle receptor preparations. Each ${ }^{125}$ I-labelled hormone binding was competed for by increasing amounts of homologous and heterologous unlabelled hormone; this displacement needed lower concentrations of homologous than heterologous hormone. When compared with MP-diet feeding, the LP diet resulted in an increased ligand concentration for half-maximal binding. In addition the specific ${ }^{125}$ I-labelled insulin and ${ }^{125}$ I-labelled IGF-1 binding increased at all hormone concentrations and, as revealed by Scatchard analysis, the hormone binding capacity also rose (only significant for low-affinity insulin receptors and high-affinity IGF-1 receptors). The HP diet had little effect on hormone binding, except to increase insulin binding at very low insulin concentrations. Hormone binding was further studied in WGA partially purified liver receptor preparations. Those preparations did not exhibit any detectable specific ${ }^{125}$ I-labelled IGF-1 binding. The specific ${ }^{125}$ I-labelled insulin binding was not altered by dietary protein level. It is concluded that the increase in skeletal muscle insulin and IGF-1 binding along with a decrease in insulin and IGF-1 in the blood from rats fed on the LP diet, is consistent with the concept of an inverse relationship between plasma hormone and hormone binding. The physiological significance with respect to metabolic adaptation of muscle remains to be established.
\end{abstract}

Dietary protein: Insulin-like growth factor-1: Rat

The intake of protein has been shown to have a major influence on the accretion of body proteins especially within skeletal muscle. The effect of protein could be exerted through both tissue amino acid supply and activation of regulatory mechanisms including neurohormonal control. As yet these highly integrated metabolic adjustments are not well understood and in protein malnutrition there are a large number of endocrine changes (Edozien et al. 1978; Turner, 1978; Whitehead \& Lunn 1979; Jepson et al. 1988). Among the hormones which could mediate regulatory responses in muscle, both insulin and insulin-like growth factor-1 (IGF-1) are likely to play key roles. Both hormones elicit anabolic actions by stimulating protein synthesis and decreasing protein degradation (Fukagawa et al. 1985; Florini, 1987; Garlick \& Grant, 1988). In addition, IGF-1 could exert its anabolic actions in muscle through mitogenic action and stimulation of cell differentiation (for review see Florini, 1987). The production and the circulating levels of insulin and IGF-1 are generally depressed under protein restriction (Phillips et al. 1978;

\footnotetext{
* For reprints.
} 
Prewitt et al. 1982; Dollet et al. 1985; Yahya et al. 1986) and impairment in liver somatogenic receptor activity (Baxter et al. 1980) and a marked insensitivity of pancreatic $\beta$ cells to various secretagogues with occasional glucose intolerance (Dollet et al. 1985; Okitolonda et al. 1988) occurs. In contrast, under protein restriction, sensitivity of peripheral tissues to insulin appears to be improved (Okitolonda et al. 1988).

Insulin and IGF-l receptors exhibit great homology in both structure and function (peptide specificity, tyrosine kinase autophosphorylation, down regulation). Insulin receptors have a low affinity for IGF-1, IGF-2 and multiplication stimulating activity (MSA, the homologue of IGF-2 in the rat) whereas IGF-1 receptors have a higher affinity for IGF-1 than for IGF-2 and a low affinity for insulin. IGF-1 and insulin could elicit similar biological responses either by cross-reaction with the appropriate heterologous receptor or by a concurrent activation of convergent effector pathways emanating from homologous receptor activation (Rechler \& Nissley, 1985; Jonas, 1988). Both IGF-1 and insulin receptors are present in skeletal muscle (Bequinot et al. 1985; James et al. 1986; Burant et al. 1987; Zorzano et al. 1988) and in most other target tissues. It is important to note that the relationship between changes in hormone receptor number and hormone action is not straightforward; differential control could be exerted through post-binding events. However, it appears that muscle, perhaps the pre-eminent target for insulin action, exhibits the closest correlation between insulin receptor number and action in states of altered nutrition, i.e. increases in hormone binding increase hormone sensitivity (see Adamo et al. 1988). To understand better the hormonal-regulated mechanism of adaptation to dietary protein, we decided to investigate IGF-1 and insulin binding to skeletal muscle and liver from growing rats subjected to various dietary protein intakes, which encompassed nitrogen restriction and excess. In contrast to other nutritional alterations (Adamo et al. 1988 ), the effect of dietary protein on insulin receptors has been poorly studied (Gill \& Hart, 1981; Grizard, 1983; Grizard \& Szczygiel, 1983). IGF-1 receptors, to our knowledge, have never been considered in this respect.

\section{MATERIALS AND METHODS}

\section{Hormones and chemicals}

Purified monocomponent insulin (no. 480) was obtained from Novo, Bagsvaerd, Denmark. Human recombinant IGF-1 (no. 1048058) was obtained from Boehringer, Mannheim, FRG. Human insulin ${ }^{125}$ I-labelled at tyr $\mathrm{A}_{14}$ (IM 166) and recombinant IGF-1 [thr 59] labelled at tyr 3 (IM 172) were purchased from Amersham International plc, Amersham, Bucks., UK. The insulin radioimmunoassay kit (Sb INSI 1) and the IGF-1 radioimmunoassay kit (IN-SOMC) were obtained from the Commissariat à l'Energie Atomique, Gif sur Yvette, France. Wheat-germ agglutinin agarose (WGA; glycaminosylex) and bovine $\gamma$-globulins (Pentex, fraction II) were from Miles Scientific, Naperville, USA. Bovine serum albumin (BSA; fraction V), $N$-2-hydroxy-ethylpiperazine- $N^{\prime}$-2-ethanesulphonic acid (HEPES), phenylmethyl-sulphonylfuoride (PMSF), $N$-acetyl-D-glucosamine, rat MSA and polyethylene glycol (PEG) were from Sigma Chemical Co, St Louis, USA; all other chemicals were reagent grade.

\section{Animals}

Eighteen male Sprague-Dawley rats from the Centre de Recherches et d'élevage des Oncins (Iffa Credo, St Germain sur l'Arbresle, France; 3 weeks old, $50 \mathrm{~g}$ ) were housed in individual cages under controlled environmental conditions (temperature $22^{\circ}, 60 \%$ relative humidity and $12 \mathrm{~h}$ dark period starting at 11.00 hours). During the period ( $7 \mathrm{~d}$ ) of growth from 47 to $80 \mathrm{~g}$ the rats were offered the control diet ( $155 \mathrm{~g}$ protein $/ \mathrm{kg}$ dry matter; MP) 
Table 1. Composition ( $\mathrm{g} / \mathrm{kg}$ dry matter) of diets

\begin{tabular}{|c|c|c|c|}
\hline Diet ... & LP & MP & $\mathrm{HP}$ \\
\hline Fishmeal & 50 & 150 & 295 \\
\hline DL-Methionine & 2 & 2 & 2 \\
\hline L-Phenylalanine & 1 & 1 & 1 \\
\hline L-Tryptophan & 0.5 & 0.5 & $0 \cdot 5$ \\
\hline L-Threonine & $1 \cdot 5$ & $1 \cdot 5$ & $1 \cdot 5$ \\
\hline Mineral mixture* & 55 & 38 & 15 \\
\hline Wheat starch-vitamin mixture $\dagger$ & 20 & 20 & 20 \\
\hline Maize oil & 20 & 20 & 20 \\
\hline Peanut oil & 60 & 46 & 15 \\
\hline Wheat starch & 350 & 300 & 250 \\
\hline Saccharose & 385 & 345 & 250 \\
\hline Agar-agar & 35 & 35 & 35 \\
\hline Choline $\S$ & 1 & 1 & 1 \\
\hline Gross energy (MJ/kg) & $17 \cdot 1$ & $17 \cdot 8$ & $18 \cdot 0$ \\
\hline
\end{tabular}

* The mineral mixture for LP, MP and HP diets respectively contained (mg): $\mathrm{CaHPO}_{4} 43660,30400$ and $12000 ; \mathrm{NaCl} 4260,2940$ and $1163 ; \mathrm{MgO} 3568,2463$ and $973 ; \mathrm{K}_{2} \mathrm{CO}_{3} 1650,1140$ and 450 ; ammonium ferric citrate 558,406 and $160 ; \mathrm{ZnSO}_{4} \cdot 7 \mathrm{H}_{2} \mathrm{O}, 36 \mathrm{I}, 250$ and $99 ; \mathrm{MnCO}_{3} 378,158$ and $62 ; \mathrm{Al}_{2}\left(\mathrm{SO}_{4}\right)_{3} \mathrm{~K}_{1} \mathrm{SO}_{4} \cdot 24 \mathrm{H}_{2} \mathrm{O} 318$,

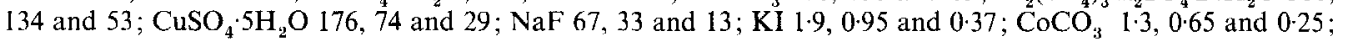
$\mathrm{SeO}_{2} 0 \cdot 75,0 \cdot 36$ and $0 \cdot 145$.

$\dagger$ The vitamin mixture in each diet contained $(\mathrm{mg})$ : cyclohexanehexol 300, aminobenzoic acid 100 , all rac- $\alpha-$ tocopherol 100 , calcium pantothenate 50 , nicotinamide 30 , riboflavin 15 , pyridoxine 10 , thiamin 10 , phylloquinone 2 , folic acid 1, biotin $0 \cdot 2$, cyanocobalamin $0 \cdot 05$, wheat starch $19381 \cdot 75$.

$\$$ Retinol and ergocalciferol were in the maize oil (1200 and $50 \mu \mathrm{g} / \mathrm{kg}$ diet respectively).

$\S$ Choline was added in water solution.

supplied at six equal and evenly-spaced meals by means of an automated device (Grizard et al. 1975). The daily intake offered approached ad lib. Each meal portion was usually consumed within $5 \mathrm{~min}$, but the feeding practice adopted avoided changes in eating pattern that might have ensued when diet composition was altered. At $80 \mathrm{~g}$ body-weight the rats were divided into three groups and fed on a diet containing 55,155 or $300 \mathrm{~g}$ protein $/ \mathrm{kg}$ (LP, MP or HP respectively, Table 1) for $11 \mathrm{~d}$. Intakes were recorded daily and water was freely available.

At the end of the $11 \mathrm{~d}$, the rats were killed by decapitation (without anaesthesia) during the post-prandial period (i.e. $1 \cdot 5-3 \mathrm{~h}$ after the meals). Blood was collected on EDTA $(1.4 \mathrm{mg} / \mathrm{ml}$ blood $)$ and plasma separated and stored at $-15^{\circ}$ before analysis. The liver and total skeletal muscles from the hind legs (i.e. a mixture of red muscles containing various proportions of fibre types) were rapidly excised, frozen in liquid nitrogen and stored at $-80^{\circ}$.

\section{Receptor preparations}

Partially purified insulin and IGF-1 receptors were obtained from preparations of liver and skeletal muscle microsomal membranes by the method of Hedo et al. (1981). Briefly, muscle samples from each animal $(6.2$ (SE 0.1) g) were homogenized in $40 \mathrm{mll} \mathrm{mm}$-sodium bicarbonate at $4^{\circ}$ using a polytron. Each liver (3.75 (SE 0.43), 8.60 (SE 0.06) and 9.29 (SE 0.40) $\mathrm{g}$ for the LP, MP and HP dietary groups respectively) was homogenized in $40 \mathrm{ml} 1 \mathrm{mM}-\mathrm{NaHCO}_{3}$ using an all-glass Dounce homogenizer. We verified that homogenization of liver using either the Dounce or Polytron apparatus yielded the same insulin binding capacity. Each tissue homogenate was centrifuged at $600 \mathrm{~g}$ for $30 \mathrm{~min}$. The pellet was discarded and the supernatant fraction further centrifuged at $40000 \mathrm{~g}$ for $30 \mathrm{~min}$. The resulting pellet was washed once with $1 \mathrm{~mm}-\mathrm{NaHCO}_{3}$ and resuspended in either $6 \mathrm{ml}$ (liver) 
or $1.2 \mathrm{ml}$ (muscle) buffer containing $50 \mathrm{~mm}$-HEPES, $2 \mathrm{~mm}$-PMSF and Triton X-100 $(10 \mathrm{ml} / \mathrm{l})$. Non-soluble material was removed by centrifugation at $100000 \mathrm{~g}$ for $30 \mathrm{~min}$. The amount of protein recovered per $\mathrm{g}$ tissue in the Triton $\mathrm{X}$-100-soluble material was constant in liver. There was a moderate, but significant $(P<0.05)$, increase as a function of dietary protein level in muscle (Table 2).

For each group, portions of the supernatant fractions containing the same amount of protein $(3.6$ (SE 0.1) mg for muscle, 5.0 (SE 0.2) $\mathrm{mg}$ for liver) were recycled five times through columns containing WGA coupled to agarose ( $1 \mathrm{ml}$ packed volume). Non-bound material was saved. Each column was then washed with $75 \mathrm{ml}$ buffer $(50 \mathrm{~mm}$-HEPES, $150 \mathrm{~mm}$ sodium chloride, Triton X-100 (1 ml/1), pH 7.6) and the bound material then eluted with the same buffer supplemented with $0.3 \mathrm{M}-N$-acetyl-glucosamine. The fractions containing the insulin receptors (the first 2 and $2.7 \mathrm{ml}$ eluted for liver and muscle respectively) were combined and used immediately for hormone-binding studies. This method provides approximately a 30-fold purification for both insulin- and IGF-1 binding capacities. Recoveries of binding activity were almost total with muscle and about $80-90 \%$ with liver. The initial non-bound material from muscle did not exhibit any specific binding whereas for liver it contained about $10 \%$ of binding activity applied to the column. There was no difference between groups in the yield of glycoproteins from the column for either tissue (Table 2).

The method used to prepare the muscle receptors differed from others reported. We purified membranes by differential centrifugation before Triton $\mathrm{X}-100$ solubilization instead of the normal direct solubilization of muscle homogenates. Furthermore, PMSF was the only protease inhibitor added. For comparison, in our hands, the method of Burant et al. (1986) and Zorzano et al. (1988) yielded the same relative affinities for homologous and heterologous ligands but both hormones exhibited a lower specific binding (results not shown).

\section{Hormone binding assays}

Assay mixtures $(0 \cdot 2 \mathrm{ml})$ were prepared containing $50 \mu \mathrm{l}$ of the appropriate WGA eluate (of equal protein content for each group; 0.96 (SE 0.06) $\mu \mathrm{g}$ for muscle, 1.02 (SE 0.10) $\mu \mathrm{g}$ for liver) either radiolabelled insulin $(0.011 \mathrm{nM})$ or IGF-1 $(0.014 \mathrm{~nm})$ plus unlabelled hormone (0-2000 nm-insulin or 0-300 nM-IGF-1) and buffer (50 mm-HEPES, $150 \mathrm{~mm}-\mathrm{NaCl}$, BSA $(0.3 \mathrm{~g} / 1)$, Triton X-100 (0.25 ml/1), 0.075 M-N-acetylglucosamine). Samples were incubated overnight at $4^{\circ}$. The receptor and bound insulin were precipitated for $10 \mathrm{~min}$ at $4^{\circ}$ by addition of $100 \mu \mathrm{l}$ bovine $\gamma$-globulin $(3 \mathrm{~g} / 1)$ and $300 \mu \mathrm{l}$ polyethylene glycol $(250 \mathrm{~g} / \mathrm{l})$ and collected by centrifugation at $10000 \mathrm{~g}$. The pellets were washed with $300 \mu$ l polyethylene glycol $(125 \mathrm{~g} / \mathrm{l})$ and recentrifuged. The tips of the tubes containing the final pellets were sliced off and radioactivity determined in a gamma counter. The specific binding was obtained by subtracting from the total binding the amount of labelled hormone that was not displaced by a large excess of unlabelled hormone (i.e. $2000 \mathrm{~nm}$-insulin or $300 \mathrm{~nm}$ IGF-1). Specific binding of label was at steady-state and a linear function of membrane protein content.

The number of binding sites and the affinity constant of the hormone-receptor interaction were determined by Scatchard analysis. With each hormone it gave a curvilinear plot consistent with either of the two receptor populations, negative cooperativity in binding or more complex phenomena (Kahn et al. 1974; Tollefsen et al. 1987; Wang et al. 1988). Binding characteristics were calculated following the two-independent-sites model. The linear regression of the bound: free ratio of hormone as a function of bound hormone was used. The slope was the apparent affinity constant and the intercept with the horizontal axis was the apparent binding capacity. With high-hormone level, the regression gave the 
Táble 2. Protein recoveries in receptor preparations from rats fed on diets containing $55(\mathrm{LP}), 155(\mathrm{MP})$ or $300(\mathrm{HP}) \mathrm{g}$ protein $/ \mathrm{kg}$

(Crude microsomal membranes were prepared from tissue samples and underwent a Triton X-100 extraction. A fraction of the extract was subjected to wheat-germ agglutinin (WGA) column chromatography and proteins were determined. Mean values with their standard errors for six and four rats/group for muscle and liver respectively)

\begin{tabular}{|c|c|c|c|c|c|c|}
\hline \multirow[t]{2}{*}{ Dietary group... } & \multicolumn{2}{|c|}{ LP } & \multicolumn{2}{|c|}{ MP } & \multicolumn{2}{|c|}{ HP } \\
\hline & Mean & SE & Mean & $\mathrm{SE}$ & Mean & SE \\
\hline \multicolumn{7}{|l|}{ Solubilized membranes $(\mathrm{mg} / \mathrm{g})^{*}$} \\
\hline Muscle $\dagger$ & 0.69 & $0 \cdot 03$ & $0 \cdot 86$ & $0 \cdot 05$ & 0.97 & 0.06 \\
\hline Liver & $15 \cdot 0$ & $1 \cdot 0$ & $14 \cdot 0$ & 1.0 & 16.0 & $2 \cdot 0$ \\
\hline \multicolumn{7}{|c|}{ Fraction of WGA-purified receptors } \\
\hline Muscle & $1 \cdot 4$ & 0.3 & 1.9 & $0 \cdot 6$ & 1.8 & $0 \cdot 2$ \\
\hline Liver & $1 \cdot 1$ & $0 \cdot 1$ & 0.8 & $0 \cdot 2$ & $1 \cdot 0$ & 0.2 \\
\hline
\end{tabular}

* mg protein/g tissue in the Triton X-100 extract, i.e. before WGA purification.

$\dagger$ Combining values from each group, the recovery of protein in the Triton X-100 extract $(y, \mathrm{mg} / \mathrm{g})$ significantly increased with increasing dietary protein level $(x, \mathrm{~g}$ protein $/ \mathrm{kg})$. Regression equation and correlation coefficient were: $y=0.0011 x+0 \cdot 65, r 0 \cdot 75, P<0.05$.

$\$$ Protein in the WGA-eluate expressed as the percentage of proteins which were applied on the column.

low-affinity constant and the total binding capacity (low-affinity + high-affinity receptors). With low-hormone level, the regression on the data corrected for the contribution of lowaffinity receptors gave the affinity constant and the binding capacity of the high-affinity receptors. However, those measurements should be considered with caution, especially with the low-affinity component.

\section{Other analyses}

Plasma insulin was determined as previously described (Manin et al. 1987) by direct radioimmunoassay (RIA) which used human insulin standard. Plasma IGF-1 underwent a $0.5 \mathrm{M}$-hydrochloric acid extraction process and $\mathrm{C}_{18}$ Sep Pak (octadecylsilyl silica cartridge) purification before RIA. This RIA used ${ }^{125}$ I-labelled human IGF-1 and rabbit anti-human IGF-1 serum as the first antibody. Goat anti-rabbit serum was used as the second antibody. The results were expressed in terms of human IGF-1 standard. Protein determination was performed by the Bradford (1976) dye method using the Bio-Rad reagent.

\section{Statistical analysis}

Six and four separate studies were performed with muscle and liver respectively. Each study was run in parallel in the three groups using a block of three animals (one in each group), which were killed at the same time interval postprandially. With each animal block, insulin and $I G F-1$ binding were measured simultaneously. Differences between groups were evaluated by one-way analysis of variance, paired Student's $t$ test and MannWhitney/Kruskall-Wallis analysis (Snedecor \& Cochran, 1971).

\section{RESULTS}

Animal characteristics

Over the whole experimental period, the mean daily dry matter intakes $(\mathrm{g})$ with their standard errors for six rats of LP, MP and HP groups were 12.1 (SE 0.4), 13.8 (SE 0.3) and 13.5 (SE 0.4 ) respectively. These dry matter intakes (and, therefore, also energy) did not 


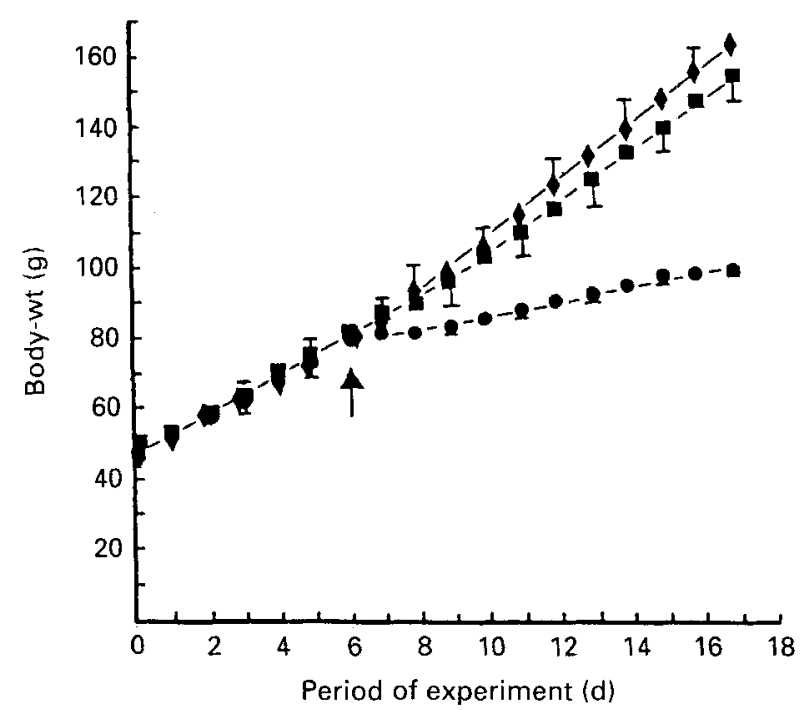

Fig. 1. Change in body-weight of growing rats submitted to different dietary protein levels (g/kg: (O), 55 (LP); (D), 155 (MP); $(\bullet), 300(\mathrm{HP})$ ). The animals first received the MP diet for $6 \mathrm{~d}$. Then $(\uparrow)$ they were divided into three groups which received the experimental diets. Points are means, and standard deviations represented by vertical bars, for six rats for the LP and HP groups and eight rats for the MP group.

differ between groups. As expected the three groups mainly differed with respect to daily protein intake $(0 \cdot 7,2 \cdot 1$ and $4 \cdot 0 \mathrm{~g}$ in the LP, MP and HP groups respectively). Low-protein diets can cause changes in appetite (see Jepson et al. 1988) but the short $(11 \mathrm{~d}$ ) experimental period was chosen deliberately to minimize inappetance which might confound metabolic interpretations. There was a small decrease (approximately $20 \%, P<0.05$ ) in the total daily carbohydrate and fat intakes in the HP group, which was a reflection of their concentration in the isoenergetic diets. Rates of growth were similar for the MP and HP groups (approximately $7.2 \mathrm{~g} / \mathrm{d}$; Fig. 1), but significantly less over the experimental period for the LP group (1.3 g/d; Fig. 1).

\section{Plasma hormones}

Total plasma IGF-1 increased as a function of daily protein intake (25.8 (SE 3.1) nu for each $1 \mathrm{~g}$ increase in dietary protein, Fig. 2). Indeed mean concentrations of IGF-1 differed significantly between all groups (30.9 (SE 0.7), 112 (SE 9), 153 (SE 12) nM for the LP, MP and HP groups respectively). Plasma insulin concentrations were lower for the LP group $(0.46$ (SE 0.07) nM) than for the MP group (1.07 (SE 0.24)) or the HP group (1.10 (SE 0.31)).

\section{Hormone binding to skeletal muscle receptors}

The characteristics of hormone binding are illustrated by the values for the MP group. Competition by unlabelled insulin for ${ }^{125} \mathrm{I}$-labelled insulin binding to partially purified receptors (Fig. 3(c)) gave $50 \%$ displacement at $0-29$ (SE 0-04) nM-unlabelled ligand. IGF-1 was fifty-one times less potent than insulin in competing for ${ }^{125} \mathrm{I}$-labelled insulin binding (50\% displacement at 15 (SE 1) nM) while MSA was 500 times less potent (values not shown). Unlabelled IGF-1 competed for ${ }^{125}$ I-labelled IGF-1 binding (Fig. 3(d)) with $50 \%$ displacement occurring at 0.09 (SE 0.02) nM. Unlabelled insulin was about sixteen times less potent $(50 \%$ displacement at 1.5 (SE 0.5$) \mathrm{nM}$ ); MSA was approximately thirty-two times less potent (values not shown). It is important to note that, according to Scatchard analysis, the 


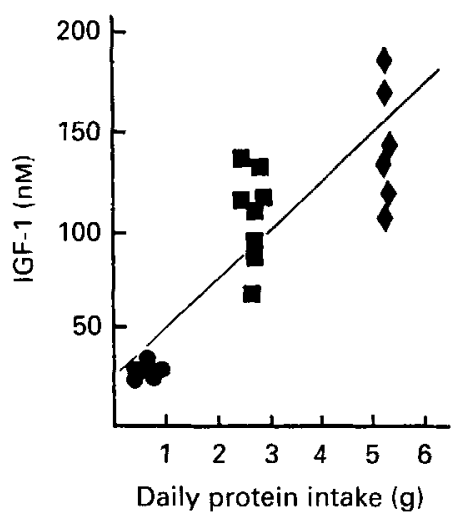

Fig. 2. Influence of protein intake on plasma concentrations of insulin-like growth factor-1 (IGF-1). Plasma samples were obtained from rats submitted to three dietary protein levels (g/kg: (O), 55 (LP); ( $)$ ), 155 (MP); $(\bullet), 300$ (HP)) for $11 \mathrm{~d}$. Plasma concentrations of IGF-1 were determined as described on p. 51; values are expressed in terms of human IGF-1 standards. The concentrations are plotted as a function of daily protein intake. Each point represents an individual. The regression equation and correlation coefficient were: $y=25 \cdot 8 x+25 \cdot 8$, $r 0.89, P<0.001$. In each group, the daily protein intakes differed from those reported in the Results because they were determined on the day before death instead of for the whole experimental period.

specific insulin binding capacities were higher than specific IGF-1 binding capacities in the muscle preparations (Table 3 ).

Compared with animals on the MP diet, rats offered the LP diet showed significant changes in hormone binding with decreased apparent affinity, and $50 \%$ displacement now occurred with insulin at 0.57 (SE 0.16) nM (Fig. $3(a v . c) ; P<0.05)$ and with IGF-1 at 26 (SE 4) nм (Fig. 3 ( $b v . d) ; P<0.05$ ). With both unlabelled ligands (low concentrations of insulin, all concentrations of IGF-1) the specific binding of ${ }^{125}$ I-labelled insulin was increased, and as revealed by Scatchard analysis, the insulin-binding capacities were improved in the LP group when compared with the MP group (only significant with the low-affinity receptors; $P<0.05$ ).

The competition curves of ${ }^{125}$ I-labelled IGF-1 binding by unlabelled hormones also showed that half-maximal binding occurred at increased ligand concentration in the LP group but the effect was significant $(P<0 \cdot 05)$ only with IGF-1 $(50 \%$ displacement at $0 \cdot 28$ (SE 0.06) and 0.09 (SE 0.02) nM in the LP and MP groups respectively, Fig. $3(b$ and $d)$ ). With both unlabelled ligands (0.014-0.9 nM-IGF-1, all levels of insulin), specific ${ }^{125}$ I-labelled IGF-1 binding was greater and total IGF-1 binding capacity was increased (only significant with the high-affinity receptors $P<0.05$ ) in the LP group compared with the MP group.

Increasing the dietary protein content had only minor effects on hormone binding compared with the MP group; $50 \%$ displacement occurred at approximately the same concentrations of unlabelled insulin and IGF-1 (Fig. $3(c$ v.e $) ;(d v . f)$ ). With both unlabelled ligands, the specific ${ }^{125}$ I-labelled IGF-l binding was similar in the two groups. The specific ${ }^{125}$ I-labelled insulin only exhibited higher values in the HP group $(P<0.05)$ at very low unlabelled hormone levels and, as revealed by the Scatchard analysis, the affinity constant of the high-affinity receptors was improved $(P<0.05)$ (Table 3 ).

\section{Hormone binding to liver receptors}

We were unable to detect any significant specific ${ }^{125}$ I-labelled IGF-1 binding in the liver receptor preparations. As with skeletal muscle, giving the LP diet seemed to increase the specific ${ }^{125}$ I-labelled insulin binding when compared with the MP diet, but it was not 


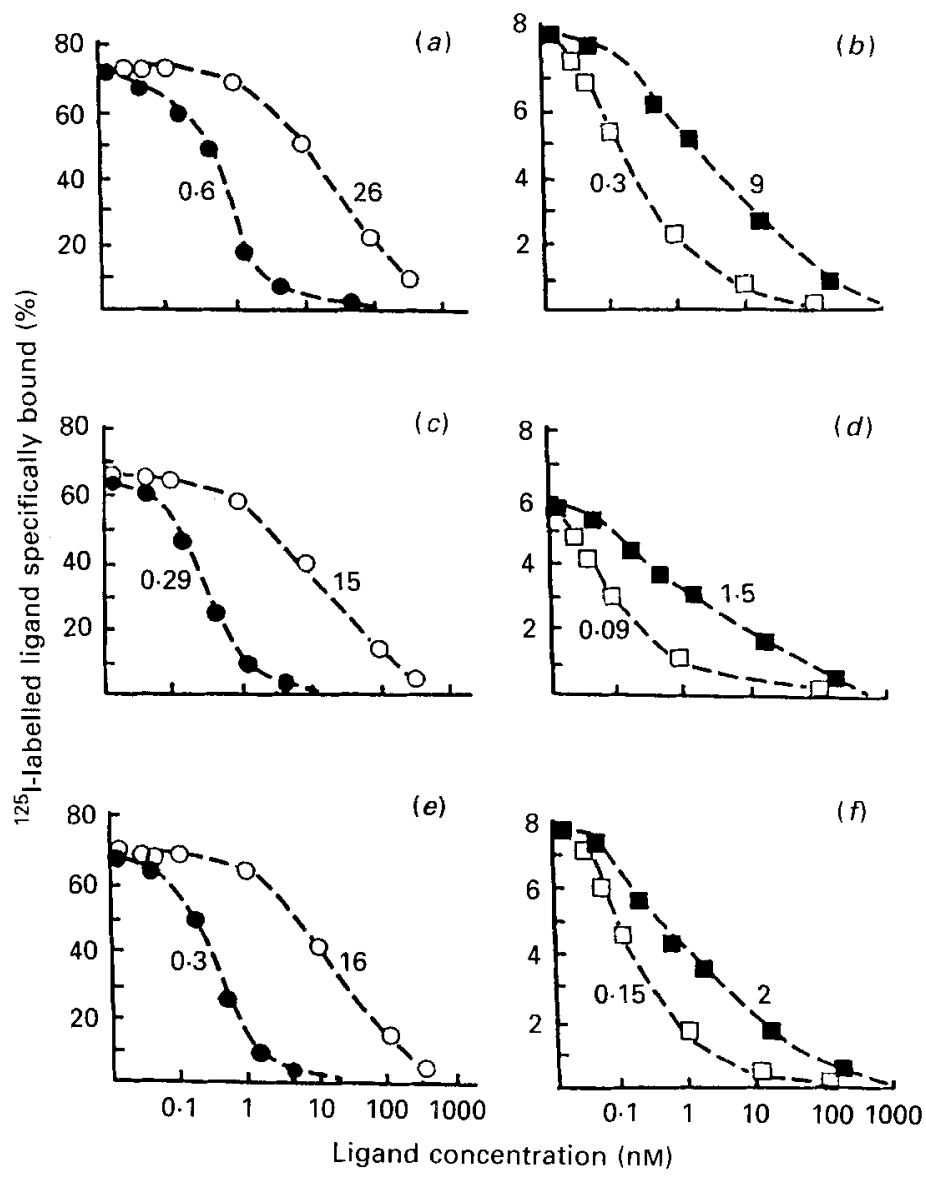

Fig. 3. Studies on specific binding of insulin and insulin-like growth factor-1 (IGF-1) to wheat-germ agglutinin (WGA) purified receptors from skeletal muscles of rats fed on the 50 (LP), 155 (MP) or 300 (HP) g protein $/ \mathrm{kg}$ diet. $(a, c, e)$ illustrate the competition between ${ }^{125} \mathrm{I}$-labelled insulin binding and either insulin (O) or IGF-1 (O). WGA eluates $(50 \mu 1)$ were incubated in $0.2 \mathrm{ml}$ containing tyr $\mathrm{A}_{14}{ }^{125} \mathrm{I}$-labelled insulin $(0.011 \mathrm{nM})$, buffer (50 mMHEPES, Triton X-100 $(0.25 \mathrm{ml} / 1), 150 \mathrm{~mm}$-sodium chloride, $75 \mathrm{~mm}$ - $N$-acetyl glucosamine, bovine serum albumin $(0.75 \mathrm{~g} / 1, \mathrm{pH} 7.7)$ and insulin or IGF-1 at the concentrations indicated. $(b, d, f)$ illustrate the competition between ${ }^{125}$ I-labelled IGF-1 binding and either insulin ( $\square$ ) or IGF-1 ( $\square$ ). Incubation conditions were similar to the insulin assay except that the ${ }^{125} \mathrm{I}$-labelled insulin was replaced by ${ }^{125} \mathrm{I}$-labelled IGF-1 $(0 \cdot 014 \mathrm{nM})$. The receptors plus bound ligand were precipitated by addition of bovine $\gamma$-globulin $(0.5 \mathrm{~g} / 1$ final concentration) and polyethylene glycol $(125 \mathrm{~g} / 1$; PEG final concentration). The precipitate was collected by centrifugation, washed once with PEG and radioactivity determined in a gamma counter. The non-specific binding (approximately 1.5 and $10 \%$ of total binding with ${ }^{125} \mathrm{I}$-labelled insulin and ${ }^{125} \mathrm{I}$-labelled IGF-I respectively) was subtracted and the result plotted as a function of total hormone concentration. Each point is the mean of six individuals with each individual measurement duplicated or triplicated. The value given on the curves are the unlabelled ligand concentration for half-maximum displacement. The values were obtained in six paired experiments, i.e. each experiment (which included competition studies of both ${ }^{125}$ I-labelled insulin and ${ }^{125}$ I-labelled IGF-1) was run using a rat from each group. Each plot exhibited very similar standard errors for the three groups; their means were for increasing ligand concentrations respectively (\%): competition between ${ }^{125}$ I-labelled insulin and insulin $4 \cdot 5,4 \cdot 8,5 \cdot 7,4 \cdot 3,2 \cdot 1$, $1 \cdot 0$ and 0.5 ; competition between ${ }^{125}$ I-labelled insulin and IGF-1 4.4, 4.3, 3.8, 3.2, 2.8, 2.1 and $1 \cdot 1$; competition between ${ }^{125}$ I-labelled IGF-I and IGF-I $1 \cdot 3,1 \cdot 2,1 \cdot 1,0 \cdot 9,0 \cdot 3,0 \cdot 2$ and $0 \cdot 1 ;$ competition between ${ }^{125}$ I-labelled IGF-1 and insulin $1 \cdot 2,0 \cdot 9,0 \cdot 7,0 \cdot 5,0 \cdot 2$ and $0 \cdot 2$. 
Table 3. Apparent hormone-binding variables $\dagger$ in muscle from rats fed on diets containing $55(L P), 155(M P)$ and $300(H P) g$ protein $/ \mathrm{kg}$

(Mean values with their standard errors for six rats/group)

\begin{tabular}{|c|c|c|c|c|c|c|}
\hline \multirow[t]{2}{*}{ Dietary group... } & \multicolumn{2}{|c|}{ LP } & \multicolumn{2}{|c|}{ MP } & \multicolumn{2}{|c|}{ HP } \\
\hline & Mean & SE & Mean & $\mathbf{S E}$ & Mean & $\mathrm{SE}$ \\
\hline Insulin & \multicolumn{6}{|c|}{ Affinity constants $(/ \mathrm{nM})$} \\
\hline High-affinity receptors & $14 \cdot 8$ & $6 \cdot 0$ & 17.8 & $3 \cdot 5$ & $25.9 *$ & 4.9 \\
\hline \multirow[t]{2}{*}{ Low-affinity receptors } & $2 \cdot 8$ & 0.6 & $3 \cdot 4$ & 0.7 & $4 \cdot 5$ & $0 \cdot 9$ \\
\hline & \multicolumn{5}{|c|}{ Binding capacities (pmol/mg protein) } & \\
\hline High-affinity receptors & 50 & 20 & 22 & 2 & 22 & 1 \\
\hline Low-affinity receptors & $33^{*}$ & 9 & 15 & 1 & 19 & 1 \\
\hline IGF-I & \multicolumn{6}{|c|}{ Affinity constants $(/ \mathrm{nM})$} \\
\hline High-affinity receptors & $10 \cdot 7$ & $3 \cdot 4$ & 12.6 & $4 \cdot 3$ & $7 \cdot 5$ & $1 \cdot 5$ \\
\hline \multirow[t]{2}{*}{ Low-affinity receptors } & 0.5 & 0.2 & $0-5$ & $0 \cdot 2$ & 0.4 & $0 \cdot 1$ \\
\hline & \multicolumn{6}{|c|}{ Binding capacities (pmol $/ \mathrm{mg}$ protein) } \\
\hline High-affinity receptors & $3 \cdot 8^{*}$ & $2 \cdot 4$ & $1 \cdot 1$ & 0.3 & 1.5 & 3.6 \\
\hline Low-affinity receptors & $12 \cdot 0$ & $3 \cdot 4$ & $8 \cdot 2$ & $3 \cdot 5$ & $12 \cdot 0$ & $3 \cdot 0$ \\
\hline
\end{tabular}

IGF-1, insulin-like growth factor 1.

* Mean values were significantly different from the corresponding MP values $(P<0.05)$,

$\dagger$ Calculated by Scatchard analysis; values are shown in Fig. 4.
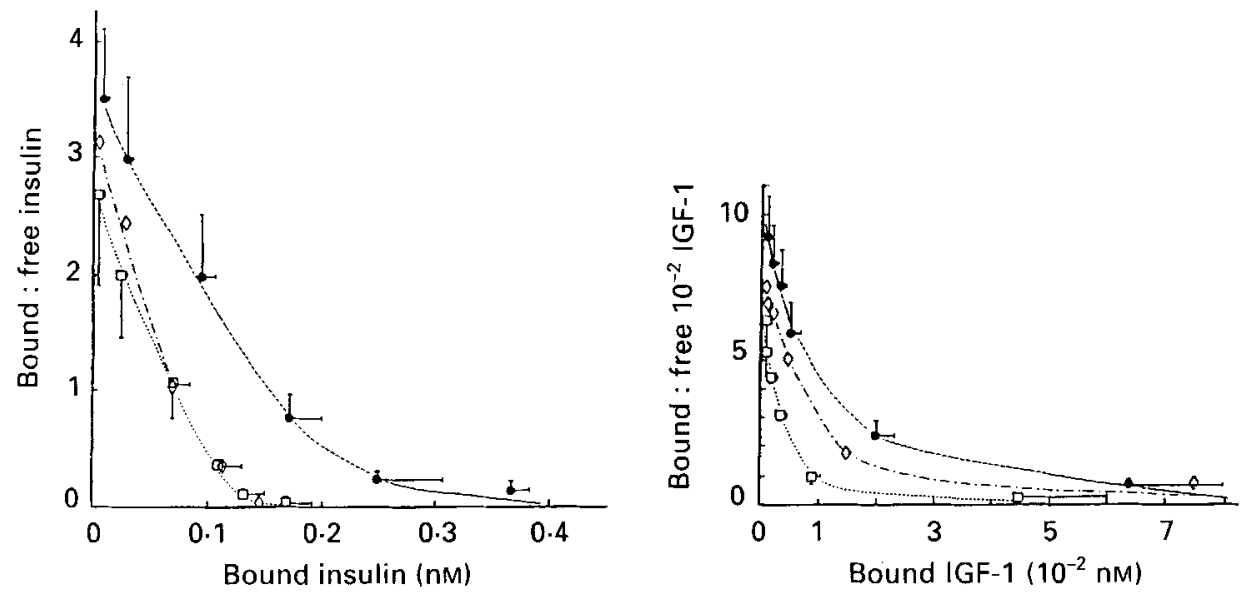

Fig. 4. Scatchard analysis of ${ }^{125}$ I-labelled insulin and ${ }^{125} \mathrm{I}$-labelled IGF-1 binding displacement by unlabelled homologous hormone to muscle receptors from rats subjected to three different protein diets $(\mathrm{g} / \mathrm{kg}$ : (O), 55 (LP); (口), 155 (MP); ( $) 300$ (HP)). Binding data were drawn from Fig. 3 with $4.8 \mu \mathrm{g}$ protein $/ \mathrm{ml}$ final concentration. Bound: free ratio of hormone is plotted as a function of bound hormone. Bound hormone $=\left(\%\right.$ of ${ }^{125} \mathrm{~J}$-labelled hormone specifically bound $) \times$ (total hormone concentration). Bound : free ratio of hormone $=\left(\%\right.$ of ${ }^{125} \mathrm{I}-\mathrm{lab}$ belled hormone specifically bound $) /\left(100-\%\right.$ of total ${ }^{125}$ I-labelled hormone bound $)$. Each point is the mean for six individual values in each group. With each point for the LP and MP groups, the vertical and the horizontal bars represent their standard errors; they are representative of the standard errors for the HP group.

significant. Giving the HP diet did not have any effect (Fig. 5). The concentration of unlabelled insulin needed to produce $50 \%$ displacement insulin binding was similar in the three groups (LP 0.91 (SE 0.17), MP 0.87 (SE 0.10), HP 0.68 (SE 0.07) nM). In addition, Scatchard analysis of the data did not reveal any modification of binding affinities and capacities (Table 4). 


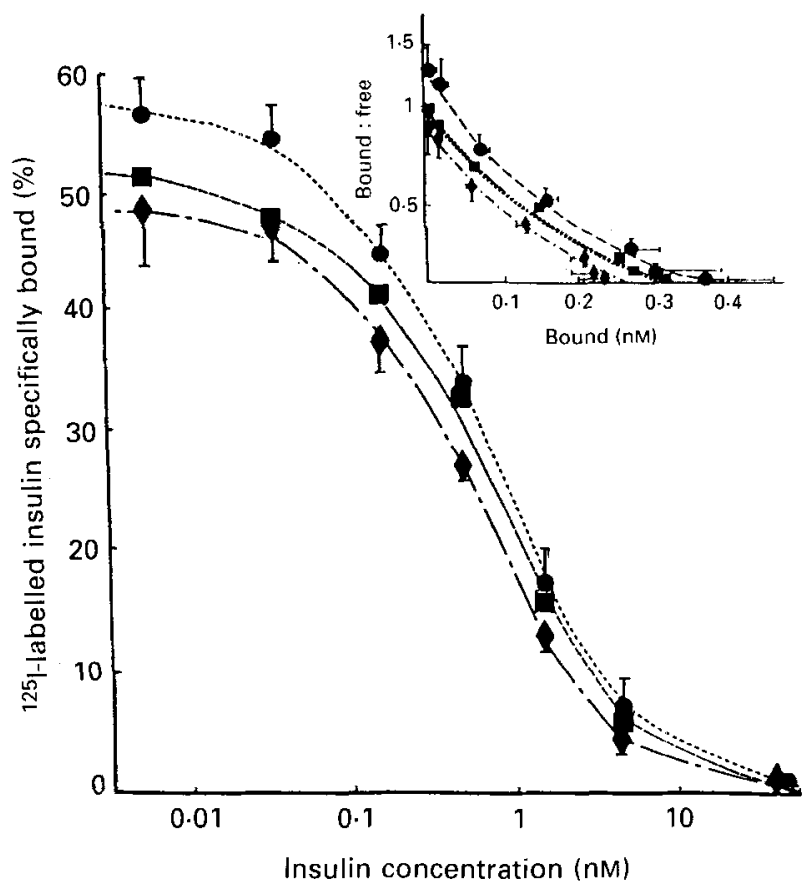

Fig. 5. Insulin binding to partially purified liver insulin receptors from rats given three different dietary protein levels (g/kg: (O), 55 (LP); (ם), 155 (MP); ( ), 300 (HP)). Wheat-germ agglutinin-purified insulin receptors $(50 \mu \mathrm{l})$ from livers were incubated with a tracer amount of tyr $\mathrm{A}_{14}{ }^{125}$ I-labelled insulin (approximately $0.015 \mathrm{~nm}$ ) and increasing concentrations of unlabelled insulin in a final volume of $200 \mu \mathrm{l}$ buffer ( $\mathrm{pH} 7 \cdot 7$ ) under conditions previously described (see p. 50). The non-specific binding, approximately $1.5 \%$ of the total binding, was subtracted. Inset shows the Scatchard plot analysis of the data. Points are means, with their standard errors for four paired experiments; i.e. each experiment was run using an individual from each group.

Table 4. Apparent insulin-binding variables* in livers of rats fed on diets containing 55 (LP), 155 (MP) or 300 (HP) g protein $/ \mathrm{kg}$

(Mean values with their standard errors for four rats/group)

\begin{tabular}{|c|c|c|c|c|c|c|}
\hline \multirow[t]{2}{*}{ Dietary group... } & \multicolumn{2}{|c|}{ LP } & \multicolumn{2}{|c|}{ MP } & \multicolumn{2}{|c|}{ HP } \\
\hline & Mean & SE & Mean & $\mathrm{SE}$ & Mean & $\mathrm{SE}$ \\
\hline \multicolumn{7}{|c|}{ Affinity constants (/nM) } \\
\hline High-affinity receptors & $6 \cdot 4$ & $1 \cdot 8$ & $6 \cdot 1$ & $1 \cdot 2$ & $6 \cdot 5$ & $1 \cdot 2$ \\
\hline Low-affinity receptors & 0.87 & 0.04 & 0.78 & $0-09$ & $0 \cdot 85$ & 0.03 \\
\hline \multicolumn{7}{|c|}{ Binding capacities (pmol/mg protein) } \\
\hline High-affinity receptors & $0 \cdot 20$ & 0.06 & $0 \cdot 19$ & 0.04 & $0 \cdot 12$ & 0.01 \\
\hline Low-affinity receptors & $0 \cdot 43$ & 0.09 & 0.40 & $0 \cdot 06$ & $0 \cdot 31$ & 0.02 \\
\hline
\end{tabular}

* Calculated by Scatchard analysis; values are shown in Fig. 5.

\section{DISCUSSION}

The present experiment analysed the effect of dietary protein on the plasma concentrations and binding to skeletal muscle and liver of both insulin and IGF-1. N restriction depressed insulin and IGF-1 in the blood, but for both hormones improved binding to skeletal muscle 
receptors. In contrast, the HP diet only had a minor effect on hormone binding despite an increase in blood IGF-1 concentrations. Thus, the design of the present study allows definition of the nutritional control of IGF-1 receptors: the hormonal changes observed could be attributed specifically to protein supply; since, on all diets, other nutrients, including energy, were substantially unchanged. In other longer-term studies, young rats, receiving low-protein diets, spontaneously reduced their food intake, resulting in protein-energy malnutrition and, therefore, creating profound effects on insulin metabolism (Adamo et al. 1988; Balage et al. 1990).

Severe $\mathrm{N}$ restriction in young growing rats resulted in a significant increase in insulin binding to WGA partially purified receptors from muscle but not from liver. This is consistent with the limited information available from growing, ruminating sheep subjected to a $25 \% \mathrm{~N}$ restriction, where increases in insulin binding to crude microsomal receptor preparations from sternocephalicus muscle occurred without any change in insulin binding to liver plasma membranes (Grizard, 1983; Grizard \& Szczygiel, 1983). Thus, these tissuespecific effects may be a general feature of the effect of protein deprivation, whatever the magnitude of restriction. In contrast, giving an HP diet only had a minor influence on insulin binding in both tissues, with a slight increase in insulin binding to skeletal muscle receptors at very low insulin concentrations. These results agree with those obtained after feeding high-protein diets to other species (liver receptors in pigs and goats, Steele et al. 1981; Gill \& Hart 1981; liver and muscle receptors in rainbow trout (Salmo gairdneri), Ablett et al. 1983). The effect of dietary protein on IGF-1 binding was similar to that in insulin binding, i.e. $\mathrm{N}$ restriction significantly increased IGF-1 binding to preparations of skeletal muscle receptors, whereas HP feeding did not.

It has been shown that preparations of WGA partially purified skeletal muscle receptors contain insulin, IGF-1 and IGF-2 receptors (Bequinot et al. 1985; Burant et al. 1987; Zorzano et al. 1988). Based on competition studies, those receptors exhibited different affinities for the three peptides, i.e. for insulin receptors, insulin > IGF-1 > MSA; IGF-1 receptors, IGF-1 $>$ insulin $>$ MSA; IGF-2 receptors, IGF-2 $>$ IGF-1, no insulin binding. It is clear in the present study that there was an increase in IGF-1 receptors in N-restricted rats since (1) there was an increase in the specific ${ }^{125}$ I-labelled IGF-1 binding at low IGF- 1 concentrations, conditions where IGF- 1 was unable to bind to the insulin receptors (see competition curves of ${ }^{125}$ I-labelled insulin by IGF-1); (2) the increase in ${ }^{125}$ I-labelled IGF-1 binding could not be related to an increase in binding to IGF-2 receptors, since in our preparations the binding of IGF-1 to IGF-2 receptors was without doubt very low since any ${ }^{125}$ I-labelled IGF-1 binding could be displaced by insulin (and insulin would not compete for ${ }^{125}$ I-labelled IGF-1 binding to IGF-2 receptors); thus a change in IGF-2 receptors would only have a minor effect on ${ }^{125}$ I-labelled IGF-1 binding. Similarly $\mathrm{N}$ restriction also increased the number of insulin receptors. Again the increase in ${ }^{125}$ I-labelled insulin binding could not be explained by an increase in IGF-1 receptors (insulin exhibited a low affinity for IGF-1 receptors, and the number of IGF-1 receptors was small compared with insulin receptors).

The fact that half-maximal binding occurred at increased concentration for both hormones in protein-deprived rats may reflect an increase in the contribution of low-affinity binding components. This could be partly explained on the basis of an increase in the binding of each labelled hormone to the heterologous receptor. The assessment of the contribution of each receptor to hormone binding would require their respective isolation (Kull et al. 1983; Stuart et al. 1984; Tollefsen et al. 1987), but no method is suitable at present for rat-tissue preparations.

The increase in skeletal-muscle insulin binding after $\mathrm{N}$ restriction may be secondary to the decrease in plasma insulin concentrations (up regulation). This concept of an inverse 
relationship between plasma insulin and insulin binding has been well documented, especially in dietary experiments on obese animals (Soll et al. 1975), and some cellular mechanisms have been established (Lopez \& Desbuquois, 1987). Based on this concept the lack of an effect of the HP diet on insulin receptors is not surprising since the HP diet did not change plasma insulin levels. Similarly, the increase in skeletal-muscle IGF-1 binding under protein restriction could be due to the decrease in plasma IGF-1 concentrations; this is based on the inverse of the down regulation of IGF-1 binding by IGF-1 observed in vitro for several cell types (for review, see Rechler \& Nissley, 1985). Increases in IGF-1 receptor number and receptor $\mathrm{mRNA}$ levels were also recorded in various tissues in response to the decrease in IGF-1 production (Lowe et al. 1989).

Due to the cross-reactivity of insulin with IGF-1 receptors, the decrease in plasma insulin could also partly contribute to the increase in IGF-1 receptors; this phenomenon has been demonstrated in vitro for human fibroblasts (Rosenfeld \& Dollar, 1982). Unfortunately, the increase in circulating plasma IGF-1 with the HP diet did not result in any change in IGF-1 binding to muscle receptors. Possibly this is because increases in plasma total IGF-1 levels might not result in a similar change in plasma free IGF-I levels. The plasma free IGF-1 concentration represents generally less than $10 \%$ of the total IGF-1 (Armstrong et al. 1989); similar values were obtained in the current study (D. Dardevet, unpublished results), but perhaps it is only this fraction which can down regulate the IGF-1 receptors. The IGF circulate in the blood bound to oligomeric protein carriers (Baxter \& Martin, 1987; Hardoin et al. 1987; Hossenlopp et al. 1987), which are modified by various nutritional conditions (Gourmelen et al. 1988). An increase in these binding proteins in the HP group would trap the IGF-1 excess and thus maintain constant the amount of plasma free IGF-1.

The biological significance of our finding in protein-restricted rats remains to be clarified, especially as far as hormone interaction is concerned. Regarding IGF-1 production, the decrease in plasma insulin without any change in liver insulin receptors partly explained the decrease in plasma IGF-1 concentration (Baxter et al. 1980; Maiter et al. 1989). An insulin defect could also modify the liver production of the IGF-binding proteins (Suikkari et al. 1988), and peptide inhibitors which can blunt the actions of IGF (Phillips \& Scholz, 1982; Phillips, 1986). The increase in both insulin and IGF-1 binding to skeletal muscle receptors of protein-restricted rats may contribute to changes in the sensitivity of target tissues, notably towards insulin since a high responsiveness of peripheral tissues to insulin is characteristic of protein-deprived rats (Okitolonda et al. 1988). It might provide a counterregulation mechanism to the effects of the decreases in plasma hormones. Based on the known biological effects of insulin and IGF-1 on skeletal muscle metabolism, this hormonal adaptation would tend to conserve muscle protein.

The authors wish to thank Gerald Lobley, Rowett Research Institute, Aberdeen, UK for his helpful discussions. They thank A. Selle, M. Sallas and Y. Bonnet for their skilful technical assistance, D. Bonin and $H$. Lafarge for the bibliographic documentation and A. Genest, M. Paccard and N. Dorr for expert assistance in the preparation of the manuscript. D. Dardevet would like to thank the Fondation Française pour la Nutrition (grant no. 10.89.2).

\section{REFERENCES}

Ablett, R. F., Taylor, M. J. \& Selivonchick, D. P. (1983). The effect of high-protein and high-carbohydrate diets on ${ }^{125}$ I] iodoinsulin binding in skeletal muscle plasma membranes and isolated hepatocytes of rainbow trout (Salmo gairdneri). British Journal of Nutrition 50, 129-139.

Adamo, M., Le Roith, D., Simon, J. \& Roth, J. (1988). Effect of altered nutritional states on insulin receptors. Annual Review of Nutrition 8, 149-166. 
Armstrong, D. G., McKay, C. O., Morell, C. \& Goddard, C. (1989). Insulin-líke growth factor-I binding proteins in serum from the domestic fowl. Journal of Endocrinology 120, 373-378.

Balage, M., Grizard, J. \& Manin, M. (1990). Effect of calorie restriction on skeletal muscle and liver insulin binding in growing rat. Hormone and Metabolic Research 22, 207-214.

Baxter, R. C., Bryson, J. M. \& Turtle, J. R. (1980). Somatogenic receptors of rat liver: regulation by insulin. Endocrinology 107, 1176-1181.

Baxter, R. C. \& Martin, J. L. (1987). Binding proteins for insulin-like growth factors in adult rat serum. Comparison with other human and rat-binding proteins. Biochemical and Biophysical Research Communications 147, $408-415$.

Bequinot, F., Kahn, R. C., Moses, A. C. \& Smith, R. J. (1985). Distinct biologically active receptors for insulin, insulin-like growth factor I, and insulin-like growth factor II in cultured skeletal muscle cells. Journal of Biological Chemistry 260, 15892-15898.

Bradford, M. (1976). A rapid and sensitive method for quantitation of microgram quantities of protein utilizing the principle of protein-dye binding. Analytical Chemistry 72, 248-254.

Burant, C. F., Treutelaar, M. K., Allen, K. D., Sens, D. A. \& Buse, M. G. (1987). Comparison of insulin and insulin-like growth factor I-receptors from rat skeletal muscle and L6 myocytes. Biochemical and Biophysical Research Communications 147, 100-107.

Burant, C. F., Treutelaar, M. K., Block, N. E. \& Buse, M. G. (1986). Structural differences between liver- and muscle-derived insulin receptors in rats. Journal of Biological Chemistry 261, 14361-14364.

Dollet, J. M., Beck, B., Villaume, C., Max, J. P. \& Debry, G. (1985). Progressive adaptation of the endocrine pancreas during long-term protein deficiency in rats: effects on blood glucose homeostasis and pancreatic insulin, glucagon and somatostatin concentrations. Joumal of Nutrition 115, 1581-1588.

Edozien, J. C., Niehaus, N., Mar, M. H., Makoui, T. \& Switzer, B. R. (1978). Diet-hormone interrelationships in the rat. Journal of Nutrition 108, 1767-1776.

Florini, J. R. (1987). Hormonal control of muscle growth. Muscle and Nerve 10, 577-598.

Fukagawa, N. K., Minaker, K. L., Rowe, J. W., Goodman, M. N., Matthews, D. E., Bier, D. M. \& Young, V. R. (1985). Insulin-mediated reduction of whole body protein breakdown. Journal of Clinical Investigation 76 , 2306-2311.

Garlick, P. J. \& Grant, I. (1988). Amino acid infusion increases the sensitivity of muscle protein synthesis in vivo to insulin. Effect of branched-chain amino acids. Biochemical Journal 254, 579-584.

Gill, R. D. \& Hart, I. C. (1981). Insulin and glucagon binding to hepatocytes in relation to circulating hormones and metabolites in goats maintained on different diets. Hormone and Metabolic Research 13, $603-609$.

Gourmelen, M., Hossenlopp, P., Cabrol, S., Saab, C., Girard, F. \& Binoux, M. (1988). Profil électrophorétique des protéines liantes des IGF (IGF-BP) dans des situations de déséquilibre nutritionnel (Electrophoretic profiles of insulin-like growth factor binding proteins in altered nutritional states). Annales d' Endocrinologie 49, 49C.

Grizard, J. (1983). Insulin binding to skelctal muscle membranes in growing ruminating sheep fed different diets. Reproduction, Nutrition, Développement 23,389-401.

Grizard, J., Prugnaud, J., Arnal, M.\& Pion, R. (1975). Effet de l'insuline sur la composition corporelle et les teneurs en acides aminés libres du sang, du foie et du muscle du rat en croissance soumis à une restriction énergétique (Effect of insulin on body composition and free amino acid levels in blood, liver and muscle of the growing rat subjected to energetic restriction). Annales de Biologie Animale, Biochimie, Biophysique 15, 569-582.

Grizard, J. \& Szczygiel, M. (1983). Insulin binding to liver plasma membranes from growing ruminating sheep maintained on different diets. Hormone and Metabolic Research 15, 475-481.

Hardouin, S., Hossenlopp, P., Segovia, B., Seurin, D., Portolan, G., Lassarre, C. \& Binoux, M. (1987). Heterogeneity of insulin-like growth factor binding proteins and relationships between structure and affinity. 1. Circulating forms in man. European Journal of Biochemistry 170, 121-132.

Hedo, J. A., Harrison, L. C. \& Roth, J. (1981). Binding of insulin receptors to lectins; evidence for common carbohydrate determinants on several membrane receptors. Biochemistry 20, 3385-3393

Hossenlopp, P., Seurin, D., Segovia, B., Portolan, G. \& Binoux, M. (1987). Heterogeneity of insulin-like growth factor binding proteins and relationships between structure and affinity. 2. Forms released by human and rat liver in culture. European Journal of Biochemistry 170, 133-142.

James, D. E., Zorzano, A., Boni-Schnetzler, M., Nemenoff, R. A., Powers, A., Pilch, P. F. \& Ruderman, N. B. (1986). Intrinsic differences of insulin receptor kinase activity in red and white muscle. Journal of Biological Chemistry 261, 14939-14944.

Jepson, M. M., Bates, P. C. \& Millward, D. J. (1988). The role of insulin and thyroid hormones in the regulation of muscle growth and protein turnover in response to dietary protein in the rat. British Journal of Nutrition $\mathbf{5 9}$, 397.415.

Jonas, H. A. (1988). Heterogeneity of receptors for insulin and insulin-like growth factor I: evidence for receptor subtypes. In Receptor Biochemistry \& Methodology, vol. 12B, pp. 19-36 [C. R. Kahn and C. Harrison, editors]. New York: Alan R. Liss.

Kahn, C. R., Freychet, P., Roth, J. \& Neville, D. M. (1974). Quantitative aspects in the insulin-receptors interaction in liver plasma membranes. Joumal of Biological Chemistry 249, 2249-2257.

Kull, F. C., Jacobs, S., Su, Y. F., Svoboda, M. E., Van Wyk, J. J. \& Cuatrecasas, P. (1983). Monoclonal antibodies to receptors for insulin and somatomedin C. Journal of Biological Chemistry 258, 6561-6566. 
Lopez, S. \& Desbuquois, B. (1987). Insulin-related changes in the subcellular distribution of insulin receptors in intact rat liver: effect of acute hypoinsulinemia induced by diazoxide, somatostatin and xylazine. Endocrinology 120, 1695-1702.

Lowe, W. L., Adamo, M., Werner, H., Roberts, C. T. \& Leroïth, D. (1989). Regulation by fasting of rat insulinlike growth factor I and its receptor. Effect on gene expression and binding. Journal of Clinical Investigation $\mathbf{8 4}$, 619-626.

Maiter, D., Fliesen, T., Underwood, L. E., Maes, G., Gerard, G., Davenport, M. L. \& Ketelslegers, J. M. (1989). Dietary protein restriction decreases insulin-like growth factor I independent of insulin and liver growth hormone binding. Endocrinology 124, 2604-2611.

Marin, M., Mizrahi, M., Vye, P., Balage, M. \& Grizard, J. (1987). The influence of acute hyperinsulinemia in the insulin-related material in brain, testis, liver and kidney. Metabotism 36, 10671072.

Okitolonda, W., Brichard, S. M., Pottier, A. M. \& Henquin, J. C. (1988). Influence of low- and high-protein diets on glucose homeostasis in the rat. British Journal of Nutrition 60, 509-516.

Phillips, L. S. (1986). Nutrition, somatomedins and the brain. Metabolism 35, $78-87$.

Phillips, L. S., Orawski, A. T. \& Belosky, D. C. (1978). Somatomedin and nutrition. IV. Regulation of somatomedin activity and growth cartilage activity by quantity and composition of diet in rats. Endocrinology' 103, $121-127$.

Phillips, L. S. \& Scholz, T. D. (1982). Nutrition and somatomedin. IX. Blunting of insulin-like activity by inhibitor in diabetic rat serum. Diabetes 31, 97-104.

Prewitt, T. E., D'Ercole, A. J., Switzer, B. R. \& Van Wyk, J. J. (1982). Relationship of serum immunoreactive somatomedin $\mathrm{C}$ to dietary protein and energy in growing rats. Journal of Nutrition 112, 144-150.

Rechler, M. M. \& Nissley, S. P. (1985). The nature and regulation of the receptors for insulin-like growth factors. Annual Review of Physiology 47, 425-442.

Rosenfeld, R. G. \& Dollar, L. A. (1982). Characterization of the somatomedin C/insulin-like growth factor 1 (SM-C/IGF-1) receptor on cultured human fibroblast monolayers: regulation of receptor concentrations by SM-C/IGF-1 and insulin. Journal of Clinical Endocrinology and Metabolism 55, 434-440.

Snedecor, G. W. \& Cochran, W. G. (1971). Statistical Methods. Ames, Iowa: Iowd State University Press.

Soll, A. H., Kahn, C. R., Neville, D. M. \& Roth, J. (1975). Insulin receptor deficiency in genetic and acquired obesity. Journal of Clinical Investigation 56, 769-780.

Steele, N. C., Rosebrough, R. W., McMurtry, J. P. \& Frobish, L. T. (1981). Hepatic insulin receptor characteristics as affected by dietary protein status in swine. Journal of Animal Science 53, Suppl. 1, $265-266$.

Stuart, C. A., Pietrzyk, R., Siu, A. K. Q. \& Furlanetto, R. W. (1984). Size discrepancy between somatomedin-C and insulin receptors. Journal of Clinical Endocrinology and Metabolism 58, 1-5.

Suikkari, A. M., Koivisto, V. A., Rutanen, E. M., Yki-Jarvinen, H., Karonen, S. L. \& Sepalla, M. (1988). Prolonged exercise increases serum insulin-like growth factor-binding protein concentrations. Journal of Clinical Endocrinology and Metabolism 66, 266-272.

Tollefsen, S. E., Thompson, K. \& Petersen, D. J. (1987). Separation of the high affinity insulin-like growth factor I receptor from low affinity binding sites by affinity chromatography. Iournal of Biological Chemistry $\mathbf{2 6 2}$, $16461 \cdots 16469$.

Turner, M. R. (1978). Effect of age and diet on hormone function. Proceedings of the Nuirition Society 37, 295-299.

Wang, C., Goldfine, I. D., Fujita-Yamaguchi, Y., Gattner, H. G., Brandenburg, D. \& De Meyts, P. (1988). Negative and positive site-site interactions and their modulation by $\mathrm{pH}$, insulin analogs, and monoclonal antibodies, are preserved in the purified insulin receptor. Proceedings of the National Academy of Sciences, USA 85, $8400 \quad 8404$.

Whitehead, R. G. \& Lunn, P. G. (1979). Endocrines in protein-energy malnutrition. Proceedings of the Nutrition Society 38, 69-76.

Yahya, Z. A. H., Bates, P. C., Dalas, S. S., Morell, D., Holder, A. T., Taylor, A. \& Millward, D. J. (1986). The effect of dictary protein concentration on bone and muscle growth and immunoreactive somatomedin $\mathrm{C}$ in the rat. Proceedings of the Nutrition Society 45, 107A.

Zorzano, A., James, D. E., Ruderman, N. B. \& Pilch, P. F. (1988). Insulin-like growth factor I binding and receptor kinase in red and white muscle. FEBS Letters 234, $257-262$. 